\title{
Examining the impact of COVID-19 and its related lockdown on food security and job losses: A case of Kumasi, Ghana
}

Frank Adusei ( $\sim$ fyadusei@gmail.com )

Ghana Ministry of Food and Agriculture https://orcid.org/0000-0002-3942-4201

\section{Article}

Keywords: Food and nutrition security, farmers, COVID-19, job loss, lockdown

Posted Date: November 4th, 2021

DOI: https://doi.org/10.21203/rs.3.rs-992274/v3

License: (1) (1) This work is licensed under a Creative Commons Attribution 4.0 International License.

Read Full License 


\section{Abstract}

The COVID-19 and partial lockdown has brought significant effects on the entire economy, especially on food security and job losses. This study was carried out in Asokwa Municipal with the objective of examining the impact of COVID-19 disease and its related lockdown on food and nutrition security and job losses. The study site form part of the cities in Ghana to experience the partial lockdown, hence it qualifies for the selection. Both primary and secondary data were used. By means of purposive sampling technique, fifty respondents were selected as sample size. The study employed a qualitative approach with a descriptive and narrative posture to the presentation, discussion and analysis of data. Open-ended questionnaire and a checklist were used for data collection through semi-structured interviews.

The results revealed that, food and nutrition insecurity, job loss and income reductions are still very common, affecting participants livelihood. Disproportionally affected are households whose income comes from farming, transporters, informal labour, as well as marketers.

It was concluded that food insecurity is not outside the impact of COVID-19 and its associated partial lockdown. Food and nutrition security are the global concern at present circumstances. The supply chain has been hit hardest by COVID-19, which causes food insecurity of most vulnerable segment of population which put them at risk. And also, most of the migrant, informal, seasonal farm workers were losing their jobs which may affect their demand for food. Therefore, the government should step-up the measures to control the pandemic without disturbing the food supply chain. The development and use of online marketing strategies where people can make orders of various produce and booked for purchases and or deliveries during a stated time range should be promoted.

\section{Introduction}

The COVID-19, which has become a global pandemic continues to affect various areas of the economy not leaving the agriculture sector which is believed to be the main pillar of most economies (Abroquah, 2020). Studies have shown that agriculture is undeniably one of the vital sectors for the world economy and it is fundamental to food security and human development (Lopez-Ridaura, Barba-Escoto and Reyna, 2019, Abdelhedi and Zouari 2020; Kogo et al). Research by Food and Agriculture Organization (FAO) has estimated that about more than $60 \%$ of the world population depend on agriculture for existence (Zavatta, 2014). It has been estimated by International Labour Organisation (ILO) that out of the total population employed in 2019, about 26.85\% are in the agricultural field (World Bank, 2019).

The United Nations Sustainable Development Goals (SDGs) call for ending hunger and achieving food security for all people by the year 2030. Achieving this goal within the next nine years is now challenged by dramatic shocks to earned income, household expenditures and agricultural value chains due to the Coronavirus pandemic. Recent estimates suggest that the economic impact of the pandemic in SubSaharan Africa specifically could be between $5 \%$ and $7 \%$ reduction in Gross Domestic Product (GDP) (Calderon et al., 2020). Estimates based on changes to income, prices and food supply suggest that the 
Coronavirus disease will dramatically increase the number of people suffering from food insecurity and undernutrition in low-and middle-income countries (Baqueano et al., 2020; FAO et al., 2020).

The pandemic threatens food security in a number of ways. On the supply side, the pandemic is particularly disruptive to post-farm agricultural value chains such as wholesale and processing logistic enterprises (Reardon et al., 2020). On the demand side, the pandemic has reduced earned income, increased poverty, and reduced household expenditures (Chetty et al., 2020; Valensisi, 2020). For the time being, economic activities in urban areas were most affected by government policies aiming to stop the spread of the virus. Due to the pandemic the global economies have been disrupted, with restrictions in both domestic and international movement leading to huge unemployment, GDP changes and job losses across the world. In the early days of the pandemic, perhaps, the agriculture sector did not receive much attention as other areas of the economy, especially tourism and airlines. Studies by Yaffe-Bellany and Corkery (2020) have it that, the closing of schools, hotels and restaurants left some farmers with no buyers for most of their produce.

In most countries, agriculture is mostly regarded as "national security" priority because of its output which are considered as necessary for existing (Charlton and Castillo 2020; Luckstead, Nayga and Snell 2020). It is incontestable fact that, COVID-19 can weaken the already unstable food security situation and agriculture sector in the early stages of the pandemic and when the nations begin to recover from it. The pandemic's impact on food security and prices depends on the functioning of the agricultural sector and what happens to the demand and supply of food items. For that reason, assessing and analyzing food security concerns also follows different approaches (Habtewold, 2018; Mulugeta and Hundie, 2012). At the start of the pandemic, many experts feared that the crisis would lead to sequences of food price increases (Ravindra et al., 2021), though, the global staple food prices have been relatively stable, most likely due to good harvests in the previous season and sufficient global storage conditions (Glauber et al., 2020). However, the pandemic has several negative effects on the domestic food supply chain and it adversely affects food security through an increase in the prices of different food items (Bene, 2020; Mogues, 2020).

While various studies have examined potential impacts of the pandemic on global and national economic indicators such as global poverty, government expenditures, GDP growth, budget deficits and employment (ILO 2020a; ILO 2020b; Nicola et al. 2020; Sumner et al. 2020; UN-Habitat and WFP 2020; World Bank 2020), there is limited information on how the pandemic and its associated lockdown policies affected individuals at the household level. Hence, understanding the household level impact and support mechanisms can be harnessed to ensure income at the local level. The trend of the spread of COVID-19 infection, the severity of its effects and high level of unpredictability worldwide calls for a comprehensive analysis of the effect of the pandemic on agriculture, dietary intake and food security.

Therefore, it is important to understand the immediate socio-economic effects of COVID-19 on agriculture, food and nutrition security and job losses while waiting for the long-term effects which involve the use of institutional data. Finally, this study would add to the growing body of literature on the 
COVID-19 pandemic by examining the socio-economic consequences of the outbreak and the induced lockdown restrictions in Kumasi, Ghana.

The paper is organized as follows. Section one has already provided the background to the study. Section two offers a literature review on relevant information about food security, job losses and COVID19 related policy environment. Section three introduces material and method while section four presents results and discussion. Finally, section five provides the conclusion.

\section{LITERATURE REVIEW}

Every disease affects not only people's health but it comes with direct or indirect effects on the socioeconomic status, agriculture, food security and sometimes dietary intake. Agriculture is one of the most essential sectors in any human development (Abdelhedi and Zouari 2020; Kogo et al. 2020; LopezRidaura et al. 2019). Studies have revealed that an outbreak of any disease (for example Spanish Flu, Asian Flu, HIV/AIDS, SARS, Ebola, and Swine Flu) has always been accompanied by an increase in hunger and most at times malnutrition (Burgui 2020) with a great impact on the economy, the environment and human activities (Siche 2020). As the disease progresses, the situation worsens, all things being equal. COVID-19 disease has spread across the world and cuts across every aspect of human life and its consequences are foreseen to linger beyond the year 2021. The pandemic has put the world on an emergency balance, with uncommon activities to confine developments and plans for fanatic distribution of public and private resources to battle the risk presented by the disease (FAO 2020a). Prior to the COVID-19 outbreak, the proportion of hungry and malnourished people across the globe was already on the rise due to such factors as impacts of climate change and an increase in conflict with more than 821 million people chronically undernourished between 2016 and 2018 (FAO, IFAD, UNICEF, WFP and WHO 2019).

The disease outbreak has worsened the trend of food insecurity and it is likely to continue if urgent steps are not taken. Although the pandemic has presented opportunities like changes in food and agricultural systems. Such changes include consumption of home-grown food, change in food distribution to the expansion of online grocery deliveries. The potential economic and food insecurity implications of the disease when compared to the 2007-2008 financial crisis which led to the food crisis will be immense due to the lockdown of activities in many countries, which was not the case during the global financial crisis. The overall objective of the study was to examine the impact of COVID-19 disease and its related lockdown on food and nutrition security and job losses in Asokwa Municipal, Kumasi.

\section{Global pandemic}

The worldwide pandemic is not a new episode for mankind as there is a number of various incidents of such. Every pandemic has affected economic growth and human activities in the world (Hanashima and Tomobe, 2012). Before the first pandemic was recorded in 1580, pandemic-like events were reported as 
early as the fifth century BC by the Greek physician Hippocrates. In the last century, the Spanish flu pandemic of 1918-19 killed between 20 and 40 million people, while the Asian flu pandemic in 1957 and Hong Kong flu in 1968 each caused an estimated 1 to 4 million deaths. The origination of pandemic starts with the development of a new subtype of influenza virus which is able to cause a disease, replicate in human beings and spread from person to person. The virus can improve its transmissibility in humans by adaptive mutation or genetic reassortment (the mixing of animal and human influenza viruses) (Gambling et al., 2004).

As of now, the world is coping with COVID-19 which is an infectious disease caused by Severe Acute Respiratory Syndrome Coronavirus 2 (SARS-CoV-2) (Mayo Clinic, 2020). Due to the novelty of its virus strain, the disease is spreading between people at a disturbing rate. It is estimated that COVID-19 will affect the global economy more than SARS. The Organisation for Economic Co-operation and Development (OCED, 2020) estimated a decrease in economic growth from $2.9 \%$ to $2.4 \%$ in 2020 and has advised that economic growth may also reach nearly $1.5 \%$ if the pandemic is prolonged. The ILO has stated that the COVID-19 crisis is the most severe tragedy the world has experienced since the Second World War (ILO, 2020).

\section{History of COVID-19}

A novel Coronavirus known as Severe Acute Respiratory Coronavirus 2 (SARSCoV-2) was first identified in the seafood market in Wuhan City, Hubei Province, China, in December 2019 (Zhu et al., 2020). Infectious lung disease caused by the Coronavirus virus is known as Coronavirus disease 2019 or, in short, COVID19 (Yu et al., 2020). On January 30, 2020 World Health Organization decreed COVID-19 outbreak as a worldwide catastrophe (Sohrabi et al., 2020).

COVID-19 is an enclosed Ribonucleic Acid (RNA) virus that is evident in humans and animals. The virus is in the Nidoviral order that belongs to the family Roniviridae, Arteriviridae, and Coronaviridae (Hassan et al., 2020; Singhal, 2020; Modi et al., 2020). The Coronaviridae family is subdivided into two, namely Torovirinae and Coronavirinae. Again, the subfamily of Coronavirinae is classed as COVs- alpha, beta, gamma, and Delta (Hassan et al., 2020). These viruses have an RNA genome, which ranges between 26 and 32- kilobases, allowing them to be isolated from several animal species. The first cases were recorded on December 8, 2019, where many patients were working and or living in Huanan Seafood Wholesale (Liu et al., 2020). On January 7, 2021, the patient's throat swab sample detected a novel coronavirus which was firstly shortened by the WHO as $2019 \mathrm{nCoV}$ (Hui et al., 2020). Corona Virus Study Group renamed this disease later as Severe Acute Respiratory Syndrome Coronavirus-2 (SARS-CoV-2). The disease was later referred to as Coronavirus disease in 2019 (COVID-19) by the WHO Gorbalenya et al. (2020). The name COVID-19 is an abbreviation where, 'CO' represents 'corona,' 'Vl' for 'virus,' and 'D' for the disease and 19 denotes the year of its outbreak (Yang et al., 2020).

Since October 2020, COVID-19 cases have spread all over the world especially to Europe, the United States of America (U.S.A), Australia, Africa and other parts of Asia. To date, the novel Coronavirus is still devastating everyday life globally, affecting 213 nations, infecting 46,435,624 people. Out of this figure, 
1,201,006 people were killed by the disease and 33,526,541 have recovered since November 1, 2020. (Worldometer, 2020). In the wake of the pandemic, 1,400 U.S citizens in Ghana requested to be repatriated with the assistance of their Embassy, even though death rates attributed to COVID-19 in Africa and Ghana were much lower compared to the U.S.A (Nyabor, 2020). It is noteworthy that the first case of COVID-19 in sub-Saharan Africa was reported in Nigeria on 28 February 2020 (WHO, 2020).

Scientists are also determined to develop potential medicines for the management of the disease, which comprises of repurposing existing drugs and producing vaccines against COVID-19. There have been several controversies surrounding the use of hydroxychloroquine as WHO has removed it from the ongoing Solidarity Trial list (WHO, 2020). Health facilities in developed countries like the U.S.A, France, United Kingdom (U.K), Spain and Italy have come under heavy patient workloads that have placed a substantial burden on intensive care unit (ICU) beds, health care workers, personal protective equipment (PPEs) and ventilators (IHME, 2020a; IHME, 2020b). In developing countries, especially Sub-Saharan Africa (SSA), there are concerns with their ability to sufficiently deal with COVID-19; partly due to medicine availability, few health facilities and research capacity.

\section{Partial lockdown in Ghana}

Ghana had its first two cases of COVID-19 infection on 12 March 2020. By 28 March 2020, the President of Ghana had announced a partial lockdown from 01:00 (local time) beginning from 30 March 2020, for 14 days. The announcement came at the time when Greater Accra, Ashanti, and Upper West Regions of Ghana had all reported cases of the virus and 141 cases had been confirmed nationwide, with 5 fatalities. During the lockdown, citizens were only permitted to leave their homes for essential items such as water, medicine, food, pay their utility bills as well as visit the bank or hospital. Five key objectives were established by the government to address the potential lockdown effects of the COVID-19 pandemic in Ghana. These were;

a) Limit and stop the importation of the virus

b) Provide adequate care for the sick

c) Contain its spread

d) Expand domestic production capability to strengthen self-reliance

e) Limit the impact of the virus on social and economic life (Ghana News Agency, 2020a).

The partial lockdown was further prolonged for another week starting on 3 April 2020. As of 15 April 2020, the confirmed cases of COVID-19 in Ghana stood at 641, out of the 50,719 tested samples (WHO, 2020). With the confirmed cases, 548 had mild to moderate symptoms, 2 had severe symptoms and 8 deaths. Out of the 641 positive cases, 66 later tested negative after treatment and had to wait for a 
second test, whereas 17 had been treated and were negative on repeated testing. As of 17 April 2020, 9 regions out of 16 in Ghana had reported COVID-19 cases. The reported regions were; Greater Accra (541), Ashanti (53), Eastern (42), Northern (10), Upper West (7), and Central, North East, Volta and Western regions had one case each. All through the partial lockdown in certain high-risk regions, Greater Accra (Accra, Tema), Ashanti (Kumasi) and Central Regions (Kasoa), there was enhanced surveillance, restriction of movement and public education.

At the end of the 3-week partial lockdown (19 April 2020), an estimated 86,000 people contact traced were recorded and 68,591 tests had so far been undertaken (Ghana News Agency, 2020a; Classfm, 2020). Out of the 68,591 screened 1,042 (1.5\%) were positive and the remaining 67,549 (98.5\%) were negative, with 9 deaths and 99 recoveries by 19 April 2020 (Ghana News Agency, 2020a). The majority of the positive cases during contact tracing and testing were travelers who had recently arrived in Ghana or persons who may have had contact with these travelers. As of 19 April 2020, Ghana was the only country in Africa to have conducted more than 60,000 COVID-19 tests and was ranked number one in Africa in terms of administering tests per million people (Ghana News Agency, 2020b).

Disinfection exercises against the potential spread of COVID-19 at marketplaces, educational institutions and even public and private facilities were also undertaken during the period of partial lockdown. Citizens were urged to continue to wear face masks, practice social distancing, frequently wash their hands with soap under running water and apply alcohol-based hand rubbing lotion (Ghana News Agency, 2020a; Zurek, 2020).

Government reasons for lifting the partial lockdown were based on a number of factors. These comprised of;
a) Better understanding of the nature of COVID-19
b) Success to date in containing its spread
c) An enhanced testing programmes
d) The identification of potential hotspots
e) The expansion of isolation and treatment centres across the country.

Despite the lifting of the partial lockdown, restrictions on religious and social gatherings and the closure of schools were still in force. Ghana's borders also remained closed (Ghana News Agency, 2020b; Asante and Mills 2020).

\section{Movement of food}


Usually, food moves from areas of production to where it is consumed whether within or across countries. Studies by Darfour and Rosentrater (2018) have it that, many African countries are net food importers. Due to the increase in food demand and changing consumption habits, Africa's food imports are rapidly increasing and these are expected to rise from US $\$ 35$ billion in 2015 to over US $\$ 110$ billion by 2025 (African Development Bank, 2020). The interesting thing is that many food producers in Africa are also known to be net food buyers (Darfour and Rosentrater, 2018). Africa has the potential to become a food exporter owing to the rich soil and appropriate climate that the continent is endowed with. The availability of food depends on what is been produced within the country and is sometimes augmented by what is imported. Countries that are intensely dependent on food imports will negatively be impacted if restrictions are imposed on producing countries. The need for food to move from one geographic location to another, whether in the same country or without poses a challenge for global food systems in the face of COVID-19. This is because the pandemic came with limitations in the movement of people. Studies show that food aid and imports have constituted about $4.7 \%$ of food needs in Ghana for over twenty years (Ayifli, 2017; Shane et al., 2000).

There is often food in the rural areas with relative scarcity in urban areas in Ghana. However, finding ways of moving food from rural to urban areas can improve its availability and accessibility. Higher postharvest losses can be expected in the near future, especially for perishable foods in areas of production due to limitations on the movement of people. The rate of spread of coronavirus with its associated lockdown, restrictions in people movement and trade flows have possible impacts on future food security. The ways that countries, governments, institutions, and communities respond to the coronavirus may also have implications for food and nutrition security and food systems policy (Hall et al., 2020). Pinto et al. (2012) and Ayifli (2017) claim that Ghana`s agricultural sector has the potential to grow fast but climate change could hinder such progress due to the country's high dependence on rainfall.

Changes in food preferences and movement of food are shifting in the short run due to COVID-19. Households are desiring foods that have a long shelf life in order not to visit the market often. There is a short-term preference towards packaged food due to perceptions of food safety or convenience. This attitude may lead to long-term changes which can develop consequences on food systems, livelihoods of farmers and dietary diversity (FAO, 2020).

Some households are hesitant to go to the market at all for fear of coming into contact with an infected person as marketplaces are disrupted with long queues due to social distancing. The safety awareness levels of the population around the world have become heightened, which has impacted food availability and access. This will improve food safety and our future dealings; however, we need to make sure that food flows from points of production to the place of consumption.

\section{The impact on job loss and food security}

The ILO reveals a considerable increase in unemployment and underemployment in the wake of the pandemic, which infers high-income losses for workers (FAO, 2020). The loss of income and remittances are reducing people's ability to buy food and compensate farmers (World Bank, 2020). As income is 
reduced, households and individuals are not able to afford basic food needs and this may compromise the quantity and quality of food. From the first confirmed case to the three months after the outbreak, the wide economic impact appears already visible in every part of the world. The economic growth was anticipated to move from $2.4 \%$ in 2019 to between 2.1 and $5.1 \%$ in 2020 based on the current state of the pandemic in SSA (Calderon et al., 2020). It is also projected by the World Bank (World Bank, 2020a) that, due to the pandemic, about 49 million people will be pushed into extreme poverty by 2020 in which SSA takes $45 \%$ of the share, making it hardest hit in terms of increased extreme poverty and hunger. Other projected results also indicated that people facing acute food insecurity globally would increase from 135 million to 270 million by the end of 2020 (WFP, 2020a; WFP 2020b). This is mainly due to losses of income from remittance and other sources, and disruption of food systems.

Arndt et al. (2020) explicated the burdens inflicted on low-income and food-insecure households, noting that workers with low education were hit the hardest. Without regular incomes or salaries, agricultural migrant and informal workers are severely affected during the lockdown periods. Lockdown measures and transport restrictions can impede farmers' access to input and output markets as observed by Cullen (2020). The percentage of household income spent on food is an indication of the level of poverty. A study by Paul et al. (2014) reveals that, in Ghana, the mean percentage of income spent on food was $65 \%$, with households spending between 40 and $79 \%$ of their earnings on food. Households will be burdened when income levels are reduced and at the same time prices of food rise. Reduced incomes affect both access to food and reduce nutrition, particularly for the most vulnerable people in society who have low incomes and are wage workers. As households try to cope with restrictions on human movement and lockdown, good nutrition will be compromised. The most vulnerable and poorest populations have relatively fewer resources to cope with the loss of jobs, reduction in incomes, an increase in food prices and sporadic food availability (FAO, 2020). Several households, especially, lowincome earners in Ghana are not able to preserve or stock food items for many days even when it is available.

Although Ghana has been regarded as one of Africa's successes stories and despite three decades of continuous growth in per capita income, most of its labour force is either trapped in traditional agriculture or low productivity jobs in the service sector (Resnick et al., 2019). This creates a challenge, not only for people dwelling in urban areas but also for those living in rural areas who will need support to cope with the outbreak of the virus.

\section{Material And Method}

\section{The Study Area}

Data for this study were collected from the residence of Asokwa Municipal. The Asokwa Municipal was whittled out of the Kumasi Metropolitan Assembly (KMA) by a Legislative Instrument (L.I.) 2294, 2018 by an Act of Parliament on the 21st day of December 2017. The Municipal comprises 18 towns clustered into 3 Zonal councils namely; Asokwa, Ahinsan and Atonsu. The Asokwa Municipality is one of forty- 
three Metropolitan/Municipal/Districts in the Ashanti Region. It is located between Latitude $6.35^{\circ} \mathrm{N}$ and $6.40^{\circ} \mathrm{S}$ and Longitude $1.30^{\circ} \mathrm{W}$ and $1.35^{\circ} \mathrm{E}$ and elevated 250 to 300 meters above sea level. In the 2010 Population and Housing Census (PHC), Ghana recorded a population of 24,658,823 compared to $18,912,079$ in 2000. Ashanti Region recorded a population of 4,780,380 in 2010 compared to 3,612,950 in 2000 and Asokwa Municipality recorded a population of 140,161 (2010). Taking into account the Municipal annual intercensal growth of $2.7 \%$ and using the 2010 population figures as the base year, the current figure could be around 187,889 (Asokwa Municipal Assembly, 2019).

Agriculture is a major contributor to the Gross Domestic Product (GDP) of the country and as such Ghana is regarded as an agrarian economy. The $2010 \mathrm{PHC}$ for the first time collected information about households engaged in agricultural activities. An agricultural household is defined as a household in which at least one person is engaged in any type of farming activity, namely crop, fish farming, tree growing and livestock rearing (GSS, 2013). Nine out of every 10 households who are into agriculture are crop farmers. Fish farming and tree planting are farming activities that are not much patronized in the Metropolis of late. Almost half (49.5\%) of the livestock reared in Kumasi Metropolis are chicken (29.9\%), goats (11.0\%) and sheep (8.6\%). (GSS, 2014)

\section{Data source and research design}

Data from secondary and primary sources were collected to implement the study. Secondary data (desk study) was sourced from journals, reports from related institutions, books, conference papers and internet articles.

Primary data was collected through semi-structured interviews (questionnaire). It was semi-structured because the questionnaires were open-ended which allowed the participants to express their beliefs, perceptions and experience. For the avoidance of contracting the COVID-19, interviews were conducted one-on-one. Observation of the setting and the participants formed part of the study. In this

research integrity, voluntary participation and confidentiality were observed as a result, the researcher respected the participant's unwillingness to disclose a piece of information. A number of actions were taken to safeguard the participants and to guarantee anonymity. For example, an informed consent form was explained verbally to the participants. This study took place between December 2020 and February 2021. Interviews lasted an average of 30 minutes.

\section{Sampling technique, sample size and data analysis}

A case study design was used to explore new and well-detailed information about the impact of partial lockdown on food security in the case site. Kumasi is the second most populated city in Ghana. The case site has been chosen by means of an extreme (or deviant) case sampling technique. Extreme case sampling is a type of purposive sampling that is used to focus on cases that are special or unusual, typically in the sense that the cases highlight notable outcomes, failures or successes. These extreme cases are useful because they often provide significant insight into a particular phenomenon, which can 
act as lessons that guide future research and practice. In some instances, extreme case sampling is thought to reflect the purest form of insight into the phenomenon being studied (Patton, 1990; Patton, 2002). Besides this, the case site is part of the first cities in Ghana to experience the first-ever partial lockdown hence it qualifies for the selection of this study. The study employed a qualitative approach with a descriptive and narrative posture to the presentation, discussion and analysis of data. An openended questionnaire and a checklist were used for data collection through semi-structured interviews.

Fifty respondents were selected as a sample size. Sample adequacy in qualitative inquiry pertains to the appropriateness of the sample composition and size. It is an important consideration in evaluations of the quality and trustworthiness of much qualitative research (Spencer et al. 2003). Samples in qualitative research tend to be small in order to support the depth of case-oriented analysis that is fundamental to this mode of inquiry (Sandelowski, 1996). Additionally, qualitative samples are purposive, that is, selected by virtue of their capacity to provide richly-textured information, relevant to the phenomenon under investigation. These types of data are mostly non-numerical and usually descriptive or nominal in nature. This means the data collected are in the form of words and sentences. Often (not always), such data capture feelings, emotions, or subjective perceptions of something.

\section{Results And Discussion}

\section{Demography of participants.}

The study involved 50 participants of which 35 were males and 15 females, representing $70 \%$ and $30 \%$ respectively. They comprise farmers (29 representing 58\%), farm labourers (10 representing 20\%), truck drivers (7 representing 14\%) and farm produce aggregators and traders (4 representing $8 \%$ ). The independent variables are the gender of respondents, education level, household size, household income and age. Table 1 below shows the details of the socio-demographic characteristics of the participants for the study.

\section{Table 1. Description of participants}




\begin{tabular}{|c|c|c|}
\hline Characteristics & Number of participants & Percentage (\%) \\
\hline $\begin{array}{l}\text { Gender } \\
\text { Male } \\
\text { Female }\end{array}$ & $\begin{array}{l}35 \\
15\end{array}$ & $\begin{array}{l}70 \\
30\end{array}$ \\
\hline $\begin{array}{l}\text { Education } \\
\text { No formal education } \\
\text { Primary } \\
\text { Junior High/Middle school } \\
\text { Secondary } \\
\text { Tertiary }\end{array}$ & $\begin{array}{c}5 \\
11 \\
9 \\
21 \\
4\end{array}$ & $\begin{array}{l}10 \\
22 \\
18 \\
42 \\
8\end{array}$ \\
\hline $\begin{array}{l}\text { Household monthly income (GHD) * } \\
\text { Unknown } \\
\text { Below } 100 \\
100-499 \\
500-999 \\
1000-1999 \\
2000-2999 \\
3000 \text { and above }\end{array}$ & $\begin{array}{c}2 \\
5 \\
6 \\
32 \\
4 \\
1 \\
0\end{array}$ & $\begin{array}{c}4 \\
10 \\
12 \\
64 \\
8 \\
2 \\
0\end{array}$ \\
\hline $\begin{array}{l}\text { Household size } \\
1 \\
2-3 \\
4-5 \\
6 \text { and above }\end{array}$ & $\begin{array}{c}10 \\
29 \\
11 \\
0\end{array}$ & $\begin{array}{c}20 \\
58 \\
22 \\
0\end{array}$ \\
\hline $\begin{array}{l}\text { Age (Years) } \\
\text { Below } 20 \\
20-29 \\
30-39 \\
40-49 \\
50-59 \\
60 \text { and above }\end{array}$ & $\begin{array}{l}6 \\
15 \\
12 \\
8 \\
6 \\
3\end{array}$ & $\begin{array}{l}12 \\
30 \\
24 \\
16 \\
12 \\
6\end{array}$ \\
\hline
\end{tabular}

Source: Author's computation

\section{Impact of COVID-19 and lockdown on participants}

The respondents were asked about the impact of the COVID-19 on their participation in farming activities. Two different answers were noticeable; first, $62 \%$ of respondents (farmers) reported no significant changes in participation in farming activities. Second, $38 \%$ of respondents reported a decrease in their participation in farming activities, as well as a decreased commitment to business activities for themselves.

The pandemic presents a challenge for the availability of hired labour for continuing farming or business activities. The participants were asked if they have been able to hire labourers for their farming or 
business activities following the onset of the COVID-19. There has been a disruption in access to hired labour in Ghana, with close to $91 \%$ of the participants reporting not being able to hire labourers. The participants were also asked about the impact of their response to COVID-19 on the cost of labour, both for casual and permanent labour. The majority of them, constituting $87 \%$ reported no changes in the cost of labour. COVID-19 is possible to have affected access to work activities outside individuals' own households. Accordingly, many people reported being cut off from work opportunities. Generally, only about $8 \%$ of participants reported being able to access work. Unavailability of labour could interrupt the production and processing of food, particularly for labour-intensive activities.

The pandemic has brought challenges with respect to accessing markets for buying and selling products. The participants were asked about their ability to sell; at the farm gate, local markets or regional markets. Participants reported considerable constraints in their ability to buy or sell their produce. All the farmers stated that they sell primarily at the farm gate to aggregators. Consequently, the farm produce aggregators also sell in local, district and regional markets to whole sellers and retailers. The lockdown and movement restrictions have affected both the availability and the cost of transportation too. The participants were asked about their ability to hire transport, the cost and its possible consequences. The researcher finds different situations. One respondent has this to say;

"Transport is available, but it is limited and at the same time costly. Poultry farmers especially were lamenting that they have hoarded eggs due to the hike in transport services, which barred them from taking them to points of sale. Only those with special permits or those who are conveying food items are allowed to move under strict supervision.

Another respondent also expressed his experience as "The sale of farm produce has been adversely affected due to unavailability of transport. As such buyers do not come for our produce. Aggregators are afraid to come here because of the COVID-19. Even when you take produce to the market, there are not enough customers."

Availability of transport showed to be the major stumbling block during lockdown and movement restriction. This was further deteriorated by strict penalty measures for those who breached the law relating to COVID-19 control. In general, challenges in the transport system affects the agri-food supply chain. The agri-food supply chain is an inter-linked multi-system of stakeholders in the agricultural sector. These stakeholders include agricultural inputs dealers, farmers, aggregators, middlemen, transport operators, food processors, marketing services and consumers.

\section{Household food and nutrition security situation}

Inadequate and or lack of financial resources to purchase food or lack of food are the two most common reasons for increased food and nutrition insecurity, even during normal periods. During a crisis like the COVID-19, these problems could be worsened. To understand how the pandemic has affected household food and nutrition security, the participants were asked if the availability of food items and their prices in the local markets had been affected, directly or indirectly. It was discovered that $31 \%$ reported a reduction 
in the availability of foods, while $79 \%$ encountered increases in food prices. The common food commodities that were cited where its availability had dropped following the onset of the pandemic were plantain, grains, roots, tubers, dried fish and seafood.

Forty-six percent of participants stated that the availability of plantain, grains, roots and tubers had negatively been affected in the markets. While the decrease in the availability of vegetables was also observed, there was a sizeable decrease in the availability of fruits in the markets. This is partly the result of the limited trading and movement during the lockdown period in the study area. The decrease in food items was not a surprise looking at the cosmopolitan nature of Asokwa, Kumasi. To understand how overall food and nutrition security status varies, the researcher used a set of seven questions to inquire from the respondents their experience. Table 2 gives a clear picture of the number of participants and how they have been affected by various food insecurity matters.

Table 2 Food Insecurity constraints

\begin{tabular}{|l|c|c|}
\hline \multicolumn{1}{|c|}{ Parameters } & $\begin{array}{c}\text { Number of participants } \\
\text { negatively affected }\end{array}$ & $\begin{array}{l}\text { Percentage } \\
\text { (\%) }\end{array}$ \\
\hline $\begin{array}{l}\text { Unable to eat preferred food due to inadequate } \\
\text { money or lack of resources }\end{array}$ & 36 & 72 \\
\hline $\begin{array}{l}\text { Ate only a few kinds of foods because of inadequate } \\
\text { money or lack of resources. }\end{array}$ & 30 & 60 \\
\hline $\begin{array}{l}\text { Worried about not having enough food to eat because } \\
\text { of inadequate money or lack of resources. }\end{array}$ & 46 \\
\hline $\begin{array}{l}\text { Had to skip a meal because there was inadequate } \\
\text { money or lack of } \\
\text { resources to get food. }\end{array}$ & 41 & 82 \\
\hline $\begin{array}{l}\text { Unable to eat healthy and nutritious food because of } \\
\text { inadequate money or lack of resources. }\end{array}$ & 6 & 12 \\
\hline $\begin{array}{l}\text { Went without eating for a whole day because of a lack } \\
\text { of money or other resources. }\end{array}$ & 9 & 18 \\
\hline $\begin{array}{l}\text { Ran out of food because of a lack of money or other } \\
\text { resources }\end{array}$ & & 82 \\
\hline
\end{tabular}

Source: Author's computation

From the Table 2 above, $36(72 \%)$ respondents were unable to eat their preferred food and $30(60 \%)$ ate only few kinds of food due to inadequate money or lack of resources. The proportion of participants who were worried about not having enough food to eat amounted to $42(84 \%)$ and those who have to skip meals due to inadequate money or other resources stood at 46 (92\%). Additionally, 41 (82\%) were unable to eat healthy and nutritious foods, $6(12 \%)$ went without food for a whole day whiles $9(18 \%)$ ran out of food due to lack of money or other resources. The researcher believes that, closed down of schools, 
especially, the primary might have been one of the causes of food insecurity. The reason been that, School feeding programs were disrupted and that compounded household food and nutrition security issues.

\section{Conclusion}

The general wellbeing and subsistence of especially human beings, are at a greater danger from COVID19 pandemic and partial lockdown. Ever since Ghana experienced the first case in March 2020, the infection rates have been on a steady rise. It seems likely that it will even take several months before the infection rate could be dropped. The effects of the pandemic must be analyzed on the basis of the dimensions of food security. The options available for achieving this include increased investment in agriculture to increase yields and some form of support for the poor and those engaged in the informal sector to enable them cope with the situation. Supporting the poor can translate into reducing the spread of the virus and its consequences on hunger and nutrition. It could be inferred from the findings that, most participants were net-food buyers therefore, stabilizing food production can improve their ability to purchase the food for household consumption and avoid temporary shocks to the food system.

The results also indicate that impacts of food insecurity vary disproportionally by different households. Significant number of the respondents were suffering from food insecurity in some indicators. For example, all the household's food insecurity status measured by for example, incidence of reducing food consumption, running out of food, skipping a meal and going to bed without eating were about $60 \%, 18 \%$, $92 \%$ and $12 \%$ respectively. The other important sector seriously impacted by the COVID-19 was the employment segment and different marketing activities. Both conditions were adversely affected by the pandemic and the performances of these sectors have dramatically changed since the disease outbreak. From the data collected so far, it could be said that nobody can be sure when a pandemic will happen, how quickly it will spread and what morbidity, mortality and economic impact it will cause.

Thus, it could be concluded that food insecurity is not outside the impact of COVID-19 and its associated partial lockdown. Food and nutrition security are the global concern at present circumstances. The supply chain has been hit hardest by COVID-19, which causes food insecurity of most vulnerable segment of population which put them at risk. And also, most of the migrant, informal, seasonal farmworkers were losing their jobs which may affect their demand for food. Therefore, the government should step up the measures to control the pandemic without disturbing the food supply chain. The development and use of online marketing strategies where people can make orders of various products and book for purchases and or deliveries during a stated time range should be promoted.

\section{Declarations}

Acknowledgments: I wish to thank all the farmers who participated.

Funding: This study received no specific financial support. 
Competing Interests: The author declares that he has no conflict of interests.

Ethical approval and consent to participate: This study follows all ethical practices during writing. Consent to participate was obtained from each participant.

Consent for publication: The author agrees and consent for the article to be published.

Data Availability: Participants of this study did not agree for their data to be shared publicly, so supporting data is not available.

\section{References}

Abdelhedi, I.T. and Zouari, S.Z. (2020). Agriculture and Food Security in North Africa: A Theoretical and Empirical Approach. Journal of the Knowledge Economy 11: 193-210. Available at: https://doi.org/10.1007/s13132-018-0528-y.

Abroquah, S. (2020). The impact of COVID-19 on Ghana's Agriculture; In the eye of a youth farmer. Available at: https://impakter.com/covid-19-ghana-agriculture/

African Development Bank (2020). Feed Africa: The High Five for Transforming Africa

Arndt, C., et al., (2020). COVID-19 Lockdowns, Income Distribution and Food Security: An Analysis for South Africa. Global Food Security 26:100-110

Asante, L.A. and Mills, R.O. (2020). Exploring the Socio-Economic Impact of COVID-19 Pandemic in Market Places in Urban Ghana. Africa Spectrum, Vol. 55(2) 170-181. Available at:

DOI:10.1177/0002039720943612

Asokwa Municipal Assembly. (2019). Composite Budget For 2019-2022: Programme Based Budget Estimates For 2019. Available at: https://www.mofep.gov.gh/sites/default/files/composite budget/2019/AR/Asokwa.pdf.

Ayifli R.W.A. (2017). Food Security Challenges in Ghana. Food Security and Sustainability 8:56.

Baqueano, F., Christensen, C., Ajewole, K. and Backman, J. (2020). International Food Security Assessment, 2020. Economic Research Service. U.S. Department of Agriculture.

Bene C. (2020). The resilience of Local Food Systems and Links to Food Security: A Review of Some Important Concepts in the Context of COVID-19 and Other Shocks. Food Security; 11:1e8.

Burgui, D. (2020). Coronavirus: How Action Against Hunger is Responding to the Pandemic Available at: https://www.actionagainsthunger.org/story/coronavirus-how-action-against-hunger-respondingpandemic 
Calderon, C., Kambou, G., and Zebaze-Djiofack, C. (2020). Africa's Pulse, No. 21, Spring 2020. The World Bank. Washington, D.C. Available at: https://doi.org/10.1596/978-1-4648-1568-3

Charlton, D. and Castillo, M. (2020). Potential Impacts of a Pandemic on the US Farm Labour Market. Applied Economic Perspectives and Policy 43:39-57. Available at: https://doi.org/10.1002/aepp.13105

Chetty, R., Friedman, J., Stepner, M. and Opportunity Insights Team (2020). How Did COVID-19 and Stabilization Policies Affect Spending and Employment? A New Real-Time Economic Tracker-Based on Private Sector Data. Working Paper.

Classfm (2020) Backlog of 18,000 COVID-19 Samples Being Cleared. Available at: https://www.Classfmonline.com/news/politics/Backlog-of-18-000-COVID-19-samples-being clearedAkufo-Addo-13128.

Cullen M.T. (2020). Coronavirus Food Supply Chain Under Strain What to do? FAO-Rome.

Darfour B, Rosentrater K.A. (2018). Agriculture and Food Security in Ghana. Agricultural and Biosystems Engineering Conference Proceedings and Presentations. Accra - Ghana.

FAO (2020). Interim Issues Paper on the Impact of COVID-19 on Food Security and Nutrition by the HighLevel Panel of Experts on Food Security and Nutrition (HLPE).

FAO (2020a). A Battle Plan for Ensuring Global Food Supplies During the COVID-19 Crisis Available at: http://www.fao.org/news/story/en/item/1268059/icode/

FAO (2020b). World Food Prices Drop in February. Available at http://www.fao.org/news/story/en/item/1264796/icode/

FAO, IFAD, UNICEF, WFP and WHO (2020). The State of Food Security and Nutrition in the World 2019, Safeguarding Against Economic Slowdowns and Downturns. FAO, Rome.

Gambling S.J., et al., (2004). The Structure and Receptor-binding Properties of the 1918 Influenza Haemagglutinin. Science Express; 303: 1838-42. Available at: DOI: 10.1126/science. 1093155.

Gorbalenya, A. E., et al., (2020). Severe Acute Respiratory Syndrome-related Coronavirus: The Species and its Viruses- A Statement of the Coronavirus Study Group. bioRxiv, 937862. DOI: https://doi.org/10.1101/2020.02.07.937862

Ghana News Agency (2020a) Successful Testing Regime and Controls Inform Lifting of Lockdown. Issued April 20 2020. Available at: https://newsghana.com.gh/successful-testingregime-and-controlsinform-lifting-of lockdown/ 
Ghana News Agency (2020b) Ghana Tops Africa's Ranking for COVID-19 Testing. Available at: https://newsghana.com.gh/ghana-tops-africas-ranking-forcovid-19-testing

Ghana Statistical Service (2013) 2010 Population and Housing Census, Ashanti Regional Analytical Report. Ghana Statistical Service, Accra, Ghana.

Ghana Statistical Service (2014) 2010 Population and Housing Census, District Analytical Report, Kumasi Metropolitan. Ghana Statistical Service, Accra, Ghana.

Glauber J, Laborde D, Martin W, and Vos R. (2020). COVID-19: Trade Restrictions are Worst Possible Response to Safeguard Food Security. International Food Policy Research Institute; 2020. p. 66;8.

Habtewold TM. (2018). Determinants of Food Security in the Oromiya Region of Ethiopia. In: Economic Growth and Development in Ethiopia. Singapore: Springer; 2018. p. $39 \mathrm{e} 65$.

Hall, B., Oehmke J.F. and Wozniak, S. (2020). Coronavirus and the Implications for Food Systems and Policy. Available at: http://www.foodsecurityportal.org/coronavirus-and-implications-foodsystems-andpolicy

Hanashima M, Tomobe K. (2012). Urbanization, Industrialization and Mortality in Modern Japan: A Spatial-Temporal Perspective. Ann GIS. 2012; 18:57-70.

Hassan, S. A., Sheikh, F.N., Jamal, S., J. K. Ezeh, J.K. and Akhtar, A. (2020). Coronavirus COVID 19: A review of Clinical Features, Diagnosis, and Treatment. Cureus 12: 3. Available at: DOI: https//dx.doi.org/10.7759\%2Fcureus. 7355

Hui, D. S., et al., (2020). The Continuing 2019-nCoV Epidemic Threat of Novel Coronaviruses to Global Health-The Latest 2019 Novel Coronavirus Outbreak in Wuhan, China. International Journal of Infectious Diseases, 91:264-266. Available at: DOI: https://doi.org/10.1016/j.jid.2020.01.009

IHME (2020a). New COVID-19 Forecasts for Europe: Italy and Spain Have Passed the Peak of Their Epidemics; UK, early in its Epidemic, Faces a Fast-Mounting Death Toll. Available at: http://www.healthdata.org/news-release/new-covid-19-forecasts-europe-italy-spain-have-passed-peaktheirepidemics-uk-early-its

IHME (2020b). New COVID-19 Forecasts: US Hospitals Could be Overwhelmed in The Second Week of April by Demand for ICU Beds. Available at: http://www.healthdata.org/news-release/new-covid-19forecasts-us-hospitals-could-be-overwhelmed-second-weekapril-demand-icu

ILO (2020). COVID-19 and the World of Work. ILO Monitor 2nd edition.

Kogo, B.K., Kumar, L, and Koech, R. (2020). Climate Change and Variability in Kenya: A Review of Impacts on Agriculture and Food Security Environment, Development and Sustainability (in press). 
Liu, S., L. et at., (2020). Online Mental Health Services in China During the COVID-19 Outbreak. The Lancet Psychiatry, 7 4, e17-e18. Available at: https://pubmed.ncbi.nlm.nih.gov/32 085841/

Lopez-Ridaura S, Barba-Escoto L, Reyna C. (2019) Food Security and Agriculture in the Western Highlands of Guatemala. Food Security. 2019; 11:817-833.

Luckstead, J., Nayga, M. R. Jr, and Snell, H.A. (2020). Labor Issues in the Food Supply Chain Amid the COVID-19 Pandemic. Applied Economic Perspectives and Policy 43: 382-400. Available at: https://doi.org/10.1002/aepp.13090

Mayo Clinic (2020). Coronavirus Disease 2019.

Modi, B., et al., (2020). Morphology, Biological Activity, Chemical Composition, and Medicinal Value of Tinospora Cordifolia (wild.) Miers. Advanced Journal of Chemistry-Section B, 2020: 36-54.

Mogues T. (2020). Food Markets During COVID-19. Special Series on COVID-19. Fiscal Affairs.

Mulugeta T, and Hundie B. (2012). Impacts of Adoption of Improved Wheat Technologies on Households' Food Consumption in South-Eastern Ethiopia: No. 1007-2016-79620.

Nicola, M., Z. et al. (2020). The Socio-Economic Implications of the Coronavirus: A Review. International Journal of Surgery 78: 185-193. Available at: https://doi.org/10.1016/j.ijsu.2020.04.018

Nyabor J. (2020) COVID-19: Over 1,400 Americans evacuated from Ghana. Available at: https://citinewsroom.com/2020/04/covid-19-over-1400-americans-evacuated-from-Ghana

OECD (2020). Combatting COVID-19 Effect on Children. Available at:

http://www.oecd.org/coronavirus/policy-responses/combatting-covid-19-s-effect-on-children-2e1f3b2f/

Patton, M. Q. (2002). Qualitative Research and Evaluation Methods (3rd ed.). Thousand Oaks, CA: Sage.

Patton, M. Q. (1990). Qualitative Research and Evaluation Methods. Thousand Oaks, CA: Sage.

Paul, K.N, Hamdiyah, A. and Samuel, A.D. (2014). Food Expenditure and Household Welfare in Ghana. African Journal of Food Science 8:164-175.

Pinto, A. D., Demirag U., Haruna A, Koo, J., and Asamoah M. (2012). Climate Change, Agriculture, and Food Crop Production in Ghana. IFPRI.

Ravindra K, Kaur-Sidhu M, Mor S, Chakma J, and Pillarisetti A. (2021). Impact of the COVID-19 Pandemic on Clean Fuel Programmes in India and Ensuring Sustainability for Household Energy Needs. Environ Int $2021 ; 147: 106335$.

Reardon, T., Bellemare, M. F., and Zilberman, D. (2020). How COVID-19 May Disrupt Food Supply Chains in Developing Countries. Available at: https://www.ifpri.org/blog/how-covid-19-may-disrupt-food-supply- 
chainsdeveloping-countries

Resnick, D., Diao, X., Hazell, P. and Kolavalli S. (2019). Agricultural Growth Key to Spur Ghana's Economic Growth. Available at: https://gssp.ifpri.info/2019/11/04/agricultural-growth-key-to-spurghanaseconomic-growth/, 2020-5-27.

Sandelowski M. (1996). One is The Liveliest Number: The Case Orientation of Qualitative Research. Res Nurs Health. 1996;19(6):525-9.

Shane, M., Teigen, L., Gehlhar, M. and Roe, T. (2000). Economic Growth and World Food Insecurity: A Parametric Approach. Food Policy 25:297- 315

Siche, R. (2020). What is The Impact of COVID-19 Disease on Agriculture? Scientia Agropecuaria 11-1. Available at. https://doi.org/10.17268/sci.agropecu.2020.01.00.

Singhal, T. (2020). A Review of COVID-19. The Indian Journal of Paediatrics, 8, 281-286. Available at: DOI: https://doi.org/10.1007/s12098- 020-03263-6

Sohrabi, C., Z., et al. (2020). World Health Organization Declares Global Emergency: A Review of the 2019 Novel Coronavirus. International Journal of Surgery, 71-76

Spencer, L., Ritchie, J., Lewis, J. and Dillon, L. (2003). Quality in Qualitative Evaluation: A Framework for Assessing Research Evidence. National Centre for Social Research. Available at: https://www.heacademy.ac.uk/system/files/166_policy_hub_a_quality_framework.pdf

Sumner, A., Hoy, C. and Ortiz-Juarez, E. (2020). Estimates of the Impact of COVID-19 on Global Poverty. UNUWIDER working paper 2020/43

UN-Habitat and WFP (2020). Impact of COVID-19 on Livelihoods, Food Security and Nutrition in East Africa: Urban Focus Available at: https://unhabitat.org/sites/default/files/2020/08/wfp 0000118161_1.pdf

Valensisi, G. (2020). COVID-19 and Global Poverty: A Preliminary Assessment: COVID-19 in Developing Countries.

WFP (2020a). COVID-19 Will Double Number of People Facing Food Crises Unless Swift Action is Taken. Press Release. World Food Program, Rome.

WFP (2020b). WFP Global Response to COVID-19. World Food Program, Rome World Bank (2020). Food Security and COVID-19. World Bank, Washington D.C. World Bank (2019). Employment in Agriculture: ILO estimate. World Bank, Washington D.C. 
World Bank (2020). The Impact of COVID-19 on Global Poverty: Why Sub-Saharan Africa Might be the Region Hardest Hit. World Bank, Washington D.C.

World Health Organization (2020). WHO Coronavirus Disease Situation Reports. Available at: https://www.who.int/emergencies/diseases/novel-coronavirus-2019/situation-reports.

Worldometer (2020). Corona Virus Update. Available at: https://www.worldometers.info/coronavirus/ Yaffe-Bellany et al., (2020). Dumped Milk, Smashed Eggs, Ploughed Vegetables: Food Waste of the Pandemic. New York Times, New York. Available at: https://www.nytimes.com/2020/04/ 11/business/coronavirus-destroying-food. html.

Yang X, et al. (2020). Clinical Course and Outcomes of Critically ill Patients with SARS-CoV-2 Pneumonia in Wuhan, China: A Single-Centred, Retrospective, Observational Study. Lancet Respir Med 2020;8(5):475e81

Yu, W. B., Tang, G.D., Zhang, L. and Corlett, R.T. (2020). Decoding the Evolution and Transmissions of the Novel Pneumonia Coronavirus (SARS-CoV-2/HCoV-19) Using Whole Genomic Data. Zoological Research 41 (3): 247. Available at: DOI: https//dx.doi.org/10.24272\%2Fj.ssn.2095-8137.2020.022

Zavatta G. (2014). Agriculture Remains Central to the World Economy. Sixty Percent of the Population Depends on Agriculture for Survival.

Zhu, S. et al. (2020). The Immediate Mental Health Impacts of the COVID- 19 Pandemic Among People with or Without Quarantine Managements. Brain Behav Immun 2020; 87:56-8. Available at: https://doi.org/10.1016/j.bbi.2020.04.045 PMID: 32315758

Zurek, K. (2020). COVID-19: President Akufo-Addo Lifts Partial Lockdown Effective Monday. Available at: https://www.graphic.com.gh/news/general-news/prez-akufoaddo-covid-update-7.html 